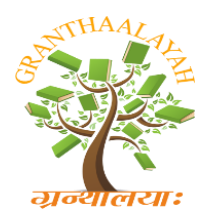

INTERNATIONAL JOURNAL OF RESEARCH -

GRANTHAALAYAH

A knowledge Repository

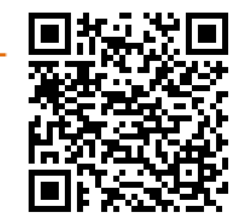

Social

\title{
A LUCID PORTRAYAL OF CONSUMMATE LIFE IN ASHALI VARMA'S -THE VICTORIA CROSS
}

\author{
S.Sayiram ${ }^{* 1}$ \\ (M.A, B.Ed. P.G.D.C.S, SLET, NELTS, M.Phil, P.G.C.T.E, (Ph.D)) \\ ${ }^{* 1}$ Research Scholar, Dravidian University, Kuppam, Andhra Pradesh, INDIA \\ ${ }^{*} 1$ P.G. Asst. in English, K.A.P.Viswanathan Hr.Sec.School, Thillainagar, Trichy, INDIA
}

\begin{abstract}
Army is one of the noblest professions. Army men usually strive for the welfare of our nation. They should be adulated for their unique sacrifice. "The Victoria Cross" throws light on the life of a unique army officer. It is a biography penned by Ashali Varma who might have felt completely satisfied with her portrayal of her parent's glorious virtues. She has depicted Prem Bhagat and Mohini who could lead a meaningful life by exchanging love perfectly and exhibiting warmth to the people who have sought succour. Prem was able to attract many people with his humanness. So, he exhibited empathy, gregariousness, veracity and tenacity to make his every endeavour successful. He never pussyfooted. He was down-to-earth. He was true to the adages "The rarer action is in virtue than in vengeance" and "To err is human; to forgive divine"

His wife was Mohini. She was an ideal wife to justify a maxim: "There is a woman behind every successful man". She could shoulder the domestic burden confidently. Her love to her husband is obvious: "I love you more than anything else in this world" (p.no.39). One can find a lot of instances in which Mohini has involved herself voluntarily to buttress Prem Bhagat even in official affair. She demonstrated her hospitality impeccably. Hence, the book "The Victoria Cross" has been written in eulogy of Prem Bhagat and Mohini who have proved to be an epitome of a couple.
\end{abstract}

Keywords:

Army, The Victoria Cross, Ashali Varma.

Cite This Article: S.Sayiram, "A LUCID PORTRAYAL OF CONSUMMATE LIFE IN ASHALI VARMA'S -THE VICTORIA CROSS" International Journal of Research Granthaalayah, Vol. 4, No. 5: SE (2016): 72-76.

\section{INTRODUCTION}

"The Victoria Cross" has been written by Ashali Varma. It is a biography narrating various events which have taken place in the life of an eminent Army officer-Prem Bhagat. Being the daughter of a glorious officer, Ashali Varma has eulogized Prem Bhagat in a consummate 
manner. She has dedicated the book to her husband, her son and her grandson who have loved Prem Bhagat forever.

\section{PREM'S GREATNESS}

Prem Bhagat was able to discharge any domestic or professional assignment meticulously. Prem was just 9 years old, when his mother died. He was taken care by his step-mother. He volunteered to shoulder the responsibility of a large family after his father's untimely demise. He was a slow learner but his elder brothers- Tutu and Tony were brilliant. He became a civil engineer. He was an expert in defusing landmines. He was attracted to a young girl called Mohini, who was one of the most beautiful girls in Poona. Mohini's father did not want to marry his daughter to Prem due to Prem's rashness.

Prem's valor during the Second World War in Sudan helped his troops overcome the fusillade of fierce attacks from the Mussolini's forces. He became triumphant of his perilous attempt, albeit the hostile living ambience. He was not placed to drink aqua pura and to live in a bivouac. Despite being novice, he showed no signs of timorousness, and he defused the landmines himself. Prem had a narrow escape from the explosion. Though he was asked to be relieved by the colonel, he refused to budge. He had single minded iron will to carry out his duty ceaselessly for 96 hours in a highly treacherous condition. It is obvious in the following lines: "I mean in actual battle, one is heavily bombed from the air, there are mines on the ground and machine gun bullets in the air. (p.no.18).... Prem continued working without breaks for food or sleep and operated with such skill and tenacity, (p.no.30) this laudable deed elevated him to bag the Victoria Cross Award. He was one of the few Indians to have bagged such a prestigious award. He was sue generic. Journals all over the world extolled Prem for his exceptional achievement. On his return to India, Prem received a hero's welcome. The greatness of Prem Bhagat is that he was never rodomontade. He did not speak about his unique feat. When he was asked to share the views on All India Radio, he informed the listeners how his group had become successful. Like many soldiers, he was prepared for war but he had a negative view about war. He used to share his war experiences with his ladylove through letters. He ate a crow in one of his letters that he was the most scared person in the world. His ladylove was over the moon about the glory which Prem had attained at a very young age.

Prem married Mohini in Poona in 1942. Being a dutiful soldier, Prem had to leave his wife for training the soldiers for the war in the East. He felt melancholic to be away from his pregnant wife. Both the couple could exchange their love through umpteen numbers of letters. They expressed their expectations about their children. Their first child was born in 1944. The first child was named Rajindra Singh Bhagat. The novelist was their second child who was born in 1952. He named his daughter Ashali because Asha meant hope and she looked like a chinese to get 'li'. He was affable to his daughter. He used to call her Papoose. Despite being gallant, Prem was too timorous to bid adieu to his daughter, when the latter joined a boarding school. After Ashali Varma's marriage too, Prem cried in bathroom.

Prem was known for his compassion too. He never hesitated to express his affection to the needy. Once, he gave his jacket to the man who was shivering in the petrol pump station without a jacket. He was gregarious. He and his wife loved rearing dogs. This compassion is apparent 
through the following sentences: "Whenever a friend or colleague talks about Prem, the first thing they say is that he was the kindest and most compassionate person they had ever known." (p.no.36)

In 1949, Prem turned the Bombay sappers into a model training centre. He initiated common dining for all ranks. Being the commandant of the Bombay Sappers was a very memorable and pleasant experience to him. He opened clubs, canteens and schools for junior commissioned officers and their families. Facility for boxing, swimming and hockey were also opened. An Olympic size swimming pool was approved. Prem opened a Group library for his men to read a few books. He has stated: "I cannot emphasise too strongly that unless the surroundings are neat and there is orderliness, a unity can never attain any degree of military efficiency" (p.no.82-83) During partition of India and Pakistan, Prem was posted as the commander of the Royal Indian engineers in Jullundur. He fathomed that there was a serious attempt from only Gandhiji to unite India and Pakistan, and the common people had the similar desire. Prem had to build a large refugee camp. His wife took risk and reached the camp from Mussourie by car. Prem was furious over the risk. This was the only time he had wrath towards his wife.

Prem's memorable act of saving Lucknow from a heavy deluge was another cap in his feather. He refused even to use a raincoat since the soldiers were striving without a raincoat. He led his soldiers successfully to avert a great disaster in Lucknow. The newspapers called Prem savior of Luck now. He bagged Param Vishisht Seva medal for his timely act. In army, Prem was concerned about young officers. The following views of Prem depict his concern for the young officers: "If we go to war tomorrow, it is these youngsters, who will die, while you and I will be twiddling our thumps in the Corps HQ." (p.no146) He wanted proper facility for them. He exhorted them to be loyal to seniors. Once, a young officer was not able to bring his wife to the army station due to the acute shortage of accommodation. Prem ordered the station commander to allot houses for the young officers. Prem's life was more with the soldiers too. So, the book glorifies the greatness of Indian army. Every soldier was known for jingoism. It is evident in the following lines: "Please sister, get the doctors to put us back our feet fast. We want to go back and fight. We never want our country to be attacked again". (p.no.153) His meticulous views were ignored prior to the India-China war in 1962. He did not favour a war against China. But Mullick and Krishna Menon had wrong calculation of the Chinese army. Unfortunately, after the India-China war, Prem and General Henderson were asked to present a detailed report about the Indo- Chinese conflict of 1962-63. Their report was comprehensive and indicted many high level officers and politicians. So, the report has not been made public. Though Jawaharlal Nehru went to the extent of believing a canard that both Prem Bhagat and Thimmaya were conspiring a military coup, Prem Bhagat was appreciative of Nehru. It is lucid in Prem's following adulation of Nehru:

In spite of Krishna Menon, the officers of the Armed forces had high regard for Nehru. Prem admired and respected him. He said he was one of the few leaders who could keep India whole. Besides being worshipped by Indians, Nehru's charisma and vision made him much admired world leader too. He did keep India from disintegrating in spite of the West constantly predicting that India would break up into smaller countries. (p.no.104) 
It is unfortunate that the glorious recipient of the Victoria cross award was not elevated to the post of Army chief in India in 1974 but General Bewoor was made army chief much to the chagrin of Prem's every well-wisher. Even Field Marshal Sam Manekshaw shared his disappointment diplomatically:

As a senior officer the characteristics I most admired in him, both as a staff officer and commander, were his friendliness, outgoing and fun loving attitude, his generosity, loyalty to his subordinates and colleagues, his out-spokenness, and that he did not mince his words. He was well read, military sound and a thinker. I had considered him MY NATURAL SUCCESSOR as the army Chief, but then the Government must have felt it would be uncomfortable to have two successive strong Army Chiefs. SO THE ARMY MISSED A FIRST RATE CHIEF. (p.no 170) In 1948, Sardar Patel had not favored the appointment of General Cariappa as the Army chief. He favored Lt.General Rajendra Singhji. When Rajendra Singhji heard of this, he informed Nehru that he would resign, if he was made the chief in preference to Cariappa. So, Prem expected the similar condition. The political interference resulted in a great ignominy to Prem. Prem's magnanimity was tangible, when he accepted to face the challenge in Damodar Valley Corporation as the chairman. The corporation was in a poor condition to result in acute power cuts in West Bengal. Prem, by his pragmatic approach, could bring drastic changes there. He redressed the genuine grievances of every employee. There were employees working without any promotion for many years. He solved this perennial problem immediately to lift the morale of employees. Having anticipated a strike for bonus from the union leaders, he announced a reasonable bonus for the employees well in advance which dumbfounded the union leaders. There was a rapport between him and the employees. From 45 megawatts, power production was augmented to 700 megawatts within 3 months to reduce the long power cuts and to foster the industrial growth in West Bengal. He led by example. Once, he found the toilets very dirty. When his order to clean the toilets was turned a deaf ear, he cleaned them himself which appalled everyone to become more dutiful. Prem bagged a UN medal for his numerous accomplishments. When Ashali asked her father about the Hindu-muslim riot in Calcutta, he told her ".... It's a terrible thing that has happened and I hope that such riots will never happen again. Always remember that there is more good in this world than evil" (p.no.124).

Prem felt that bureaucracy stopped our country from becoming a leading power. He was against red tapism. He desired many excellent ideas to be implemented. He was instrumental in building the highest road of the world in Leh which is 20000 feet above the sea level. When the novelist came to know of her father's eternal fame in Leh too, she was astounded. One can gauge consummacy in Prem's life since he has achieved in his every attempt. It is unfortunate that Prem died of gross medication. Just before his death, he informed his daughter that he was satisfied because he had conducted a marriage for his daughter, and built a home for his wife.

\section{MOHINI AS A CONSUMMATE WIFE}

Prem's wife Mohini was very dutiful to her husband. Before marriage, she exchanged romance with her husband through epistles which provided Prem the much needed solace. Initially, she shouldered the responsibility of her large family since Prem was the first person in his family to be married. She used to express her impeccable hospitality, whenever anybody visited her home. She and her daughter knit even scarfs for the soldiers. She accommodated more than 200 
Muslims who were affected in a communal riot in Kolkata. She was overwhelmed by the veneration which her husband received from the thankful people and officers and employees of Army. She had a laudable conviction that she had been married to Prem in their previous birth. She believed strongly that she would unite with him. So, she never cried after Prem's death. Moreover, she felt that he was physically not with them. She could live for 30 years after her husband's death. She involved voluntarily herself to help many war widows in their domestic, social and financial problems. She died of carcinoma for which she had not undergone any treatment. She depended only on palliative therapy. Her sufferings were alleviated by her grandson who used to take her perfectly.

The book "The Victoria cross" portrays a lot of events which have happened in the life of both Prem Bhagat and his wife. As they were great, they were able to lead a completely satisfied life to gladden their kith and kin. One can infer a lot of lofty ideals in the book. Being the daughter of Prem and Mohini, the novelist has tried to depict Prem's grandeur through the opinion of various people who have been associated with Prem. This distinctive compilation is exhaustive. She has ended the book with the crucial message and the 'gift' which she has received from her mother. The following utterances have highlighted how her mother's gift and the timely message have helped the novelist overcome poor amour propre: What I remembered most was that when I was growing up and going through an awkward stage, and thinking I looked so ugly, my mother said, "Ashi, my sweetheart, you have to feel beautiful if you want to look beautiful." It was a lesson I passed on to my son. She convinced me that I was beautiful and brave and brilliant. Most of all she believed in me. This is the greatest gift a mother can pass on to a child. (p.no.238).

\section{CONCLUSION}

The novelist regretted that she had not been with her mother in the last few years of her life. She found many old people suffering with their sons or daughters living abroad and coming for only sojourn. She has wanted those youngsters to come back to India since the parents are always in need of their children. Her view is incontrovertible: No one can replace a child for a parent. The book is certain to instigate the jeunesse to be more sanguine, jingoistic, affable, industrious, humane, audacious, veracious and dutiful. It highlights the significance of a son's or a daughter's crucial care to the parents. So, it is expected that old age homes will peter out. Hence, it may be stated that the book makes its reader a humane.

\section{REFERENCES}

[1] Varma, Ashali. The Victoria Cross. (Pearson, New Delhi,2013). 